\title{
Creation Of Multilingual Teaching Materials Focused On Content And Background Of Ngada Culture For Primary 1st Grade
}

\author{
Yosefina Uge Lawe ${ }^{1}$, Maria Desidaria Noge ${ }^{2}$, Kristoforus Portasius Dosi Rato ${ }^{3}$, Dony Novaliendry ${ }^{4}$ \\ ${ }^{1}$ Primary School Teacher Education Study Program, STKIP Citra Bakti, Flores NTT, Indonesia \\ ${ }^{2}$ Primary School Teacher Education Study Program, STKIP Citra Bakti, Flores NTT, Indonesia \\ ${ }^{3}$ Primary School Teacher Education Study Program, STKIP Citra Bakti, Flores NTT, Indonesia \\ ${ }^{4}$ Electronic Department, Faculty of Engineering, Universitas Negeri Padang, Padang, Indonesia,Electronic \\ Department, National Kaohsiung University of Science and Technology, Kaohsiung, Taiwan \\ dony.novaliendry@ft.unp.ac.id
}

Article History: Received: 11 January 2021; Accepted: 27 February 2021; Published online: 5 April 2021

\begin{abstract}
This research was conducted in line with the development of existing technology. The teaching materials are developed using the ADDIE model, which consists of five steps, namely: 1) analyze, 2) design, 3) development, 4) implementation, 5) evaluation. In this study, sources of data were obtained from teachers as material / content experts, lecturers as language experts, and design experts. Components assessed by material experts are content feasibility, linguists on the appropriateness of language use, design experts on product design appropriateness. The suitability of the developed teaching materials in terms of the results of the assessment or validation of content or material experts obtained a score of 79 with an average of 4.4, and local language experts received a score of 44 with an average of 3.6, Indonesian language experts got a score of 43 with an average of 4.7. Product design experts obtained a score of 43 with an average of 3.9. Thus, multilingual teaching materials based on content and the local cultural context of the Ngada ethnic group on Theme 6 Clean, Healthy, and Beautiful Environment can be used.

Keywords: teaching materials, multilingual, content, and context, local culture.
\end{abstract}

\section{Introduction}

In implementing the 2013 curriculum, it was identified that learning in schools emphasizes aspects of the learning experience that are bystudents' interests and talents. Seeing that the characteristics of students in each region in Indonesia are different from one another, it is necessary to identify elements of local culture (local wisdom) in student learning resources to make the class action to achieve meaningful learning experiences $[1][2][3][4][13]$.

Meaningful learning will be obtained if children learn by their social environment, so those cultural elements cannot be separated in designing learning at school. Also, in the 2013 curriculum framework, it is stated that in compiling and developing learning activities must pay attention to the principles of preparation and development by the conditions in the education unit both the initial abilities of students, interests, motivation to learn, talents, potential, social skills, emotions, learning styles, special needs, learning speed, cultural background, norms, values, and/or the environment of students. One of the learning approaches that must be taken by a teacher is to prepare teaching materials. According to Belawati, et al. [5], teaching materials have a significant role in the learning process, namely as a reference for which content is absorbed in the learning process to become knowledge. Meanwhile, for teachers, teaching materials become a reference for delivering an experience to students. The function of preparing this teaching material is as a guide for teachers and students so that the competencies to be achieved are based on the curriculum. Teaching materials prepared by the teacher must be designed according to the needs and settings of the environment around the students.

Many teachers still use ready-made teaching materials such as thematic books that have been provided by the government or Student Worksheets (LKS), which are the result of a publisher that may not be suitable for the environment in which the student is studying. This condition can certainly make it difficult for students to understand the material they should be good at. For this reason, it is necessary to develop context-based and content-based teaching materials in the student's environment because it can spur students to be able to learn well in the surrounding environment.

Nowadays, students have started to forget the local cultural elements, whichare influenced by technological developments that can access external cultural influences, causing students to fail their own culture. To respond to this, a professional teacher must be able to return students to learn to know the local community's customs and culture, and this can be done by developing teaching materials that can spur students to be able to discover their own culture. The development of teaching materials by prioritizing local wisdom elements, especially the local culture of the Ngada people, has a variety of cultures that are very suitable for inclusion in learning in elementary schools. And assessed the local wisdom of the Ngada community in its implementation to produce thematic teaching materials relevant to the 2013 curriculum framework. 
Local cultural elements such as traditional musical instruments, folklore, traditional rituals, cultural sites, and pets are suitable for students' inclusion in teaching materials, especially students in elementary schools. However, the teaching materials currently used in schools still use printed teaching materials provided by the government, which may not prioritize the local community's local cultural elements. As previously explained, this printed teaching material is also considered less attractive and makes students quickly bored in reading it. Teachers need to compile teaching materials that are more interesting and contextual [6].

The development of teaching materials based on the content and local cultural context of Ngada can be done in more than one language, namely regional language and Indonesian, and this is to make it easier for students to know the material contained in the teaching material, which is adjusted to the local cultural context. Therefore, the development of this teaching material uses multilingual.

The term Multilingual refers to the description of a speaker who speaks more than two or more languages. Multilingual are people who have or use several languages in their activities. The use of regional language and Indonesian in one teaching material makes it easier for students, especially low-grade students because their mother tongue still influences them.

The research objectives in this development are as follows: (1) to produce multilingual teaching materials based on the local culture of the Ngada ethnic group on the theme of a Clean, Healthy, and Beautiful Environment that is by the characteristics of elementary school students in grade 1, (2) to determine the quality of product test results for material development Multilingual teaching based on the local culture of the Ngada ethnic group on the theme of a Clean, Healthy and Beautiful Environment for grade 1 elementary school students.

\section{Literature Review}

According to Lestari [7], teaching materials are a set of learning tools, methods, limitations, and evaluating ways designed systematically and attractively to achieve the expected goals, namely achieving competencies and sub-competencies with all their complexities.

Teaching materials or learning materials are as follows 1) printed teaching materials, and 2) electronic/nonprinted teaching materials. The teaching materials developed by the researchers are multilingual. The term Multilingual in learning is learning that uses two languages or bilingual as a medium of instruction. The languages used are Indonesian and regional. The purpose of implementing multilingualism in classroom learning is to provide students with language skills that include listening, speaking, reading, and writing skills in the language. In this study, researchers will develop bilingual teaching materials, namely teaching materials that use Indonesian and teaching materials that use regional languages. Indonesian is the Republic of Indonesia's official language, as stated in Article 36 of the 1945 Indonesian Constitution. In the world of education, Indonesian has become the language of instruction in every teaching and learning process. Simultaneously, regional language is the language used in a region in a country and is used in daily conversation by residents in that area. A local speech or regional language is very close to the ethnic group that gave birth to and uses it. Language is the main supporting element of traditions and customs. In the world of education, local languagesare used as instruction for teachers in classroom learning activities.

Multilingual means the use of more than two languages by a speaker in his interactions with other people. Thematic learning in Indonesian, Bajawa regional languages, and English is learning in which learning material, teaching and learning processes, and assessments are delivered in Indonesian, English, and regional languages. Multilingual learning is a way used by teachers to create an atmosphere that allows students to learn by using trilingual instruction.

The Multilingual Indonesian Dictionary (KBBI) can use more than two languages. From the description above, it can be concluded that multilingualism is the use of more than two languages in learning activities. In this study, researchers will develop language teaching materials, namely teaching materials that use Indonesian, teaching materials that use regional languages, and English.

Culture is defined as a collection of life experiences in society [8]. The community's life experiences are very many and varied, including the behavior and beliefs (beliefs) of the community itself. Alexon [8] also explains that culture is defined as the collective programming of thoughts that distinguishes people from other categories. In this case, it can also be said that culture is collaborative programming, which describes a process that binds everyone as soon as he is born into the world [9]. 
Also, it stated that culture is close to students' environment, so it is hoped that it will be a driving force in improving student learning outcomes. Then Ajawaila [7] explains that culture is closely related to people's local life in an area. Local culture is a cultural characteristic of a community group. The elements referred to can be in the form of religious values, customs, habits, advice from ancestors, etc.

From some of the opinions above, it can be concluded that local culture is positive human behavior in dealing with nature and the surrounding environment, derived from religious values, moral laws, customs, ancestral advice, ingrained habits, and customary norms.

\section{Method}

The type of research to be carried out in this research is development research. Development research is one type of study whose main priority is developing and validating certain products. Development research is a method used to produce a specific product such as prototypes, designs, learning materials, media, strategies, and evaluation tools in learning. The purpose of development research in this study is to develop and produce printed teaching materials based on local culture. The development of multilingual teaching materials uses the ADDIE development model. Novaliendry [10][12] explains that this model consists of five steps, namely (1) analysis, (2) design, (3) development, (4) implementation, and (5) evaluation. This model's choice is based on the consideration that this model is developed systematically and is based on the theoretical foundation of learning design. This model is structured programmatically with a systematic sequence of activities to solve learning problems related to learning resources that suit students' needs and characteristics. The development procedure used is the ADDIE model development procedure, which consists of five steps (1) analyze, (2) design, (3) development, (4) implementation, and (5) evaluation. This product trial uses an instrument in the form of a compiled questionnaire. Content/material experts assessed the tool in the form of a questionnaire on the content's appropriateness, design experts on the suitability of the design of teaching materials development, and linguists on the appropriateness of use. The test subjects in this study included: (1) class I teachers as content/material experts, (2) regional language experts, (3) STKIP Citra Bakti lecturers as product design experts, and (4) Indonesian language experts.

The data collection methods used in this study are as follows: (1) data regarding the material in the theme of a clean, healthy, and beautiful environment that can be integrated with the local cultural context of the Ngada community collected through class I syllabus analysis, (2) data regarding information The characteristics of the local culture of the Ngada community as the content and context of printed teaching materials on the theme of a Clean, Healthy and Beautiful Environment were collected through interviews with community leaders and traditional leaders in Ngada Regency, (3) data on the quality of printed teaching materials seen from the content, presentation, language and feasibility of use were obtained from teachers and students in a limited trial using a questionnaire that had been compiled. The questionnaire is a data collection method carried out by giving or asking questions or written statements to the respondents. In this research, the data collection instrument on developing printed teaching materials is a questionnaire that refers to the assessment of the National Education Standards Agency (BNSP), which consists of a content component. Theory. The BSNP instrument was used because the BSNP assessment instrument was used to assess printed teaching materials. This study's data sources were obtained from teachers as material/content experts, lecturers as language experts, design experts, and students as prospective product users. This study's data sources were obtained from teachers as material/content experts, lecturers as language experts, design experts, and students as prospective product users. The components assessed by the material expert are content appropriateness, linguists on the suitability of language use, design experts on the feasibility of learning design, while students are on the feasibility of using the product.

\section{Results and discussion \\ 3.1 Results}

The multilingual printed teaching materials developed to refer to the ADDIE development model [11] "I am satisfied at this point to conclude that the ADDIE model is merely a colloquial term used to describe a systematic approach to instructional development, virtually synonymous with instructional. System development (ISD) ".

Molenda [11] states that the ADDIE model is a general development model commonly used in development research because it is sequential.

The stages of this model consist of 5, namely: (1) Analyze, (2) Design, (3) Development, (4) Implementation, and (5) Evaluation. The materials in this multilingual printed teaching material are based on the content and the local cultural context of the ethnic Ngada. The following is an explanation of the stages of developing teaching materials based on the ADDIE model. The researcher analyzes the teaching materials in the analysis stage and determines the teaching materials to be developed. Teaching materials to be developed are in the form of a class 1 elementary school book with theme 6 revision of 2017. After analyzing the teaching materials, the researcher then analyzes the essential competencies that students will achieve. According to those used in schools, the vital competencies analyzed are the government's necessary competencies through Permendikbud No. 24 of 2016 . The 
design stage is divided into two phases: (1) Preparing a framework or draft of multilingual printed teaching materials, (2) Collecting pictures related to the material. The teaching materials developed are divided into four sub-themes, and each sub-theme has six lessons.

Sub-theme 1 discusses my home environment, sub-theme 2 discusses the ground around my house, subtheme 3 discusses our school environment, and sub-theme 4 discusses working together to clean the environment. The development of teaching materials is an effort to compile teaching materials that are more focused on a teaching material product. The teaching materials developed are Multilingual Teaching Materials Based on Content and Local Cultural Contexts: ethnic Ngada Theme 6 Clean, Healthy, and Beautiful Environment. The teaching materials that will be produced will consist of two languages, namely Indonesian and the local language of Ngada (ethnic Golewa), which are combined into one product. Teaching materials that will be displayed or used in the teaching-learning process have been planned and designed according to the field's needs or students. The materials used are by the level of understanding of the students themselves. Besides that, the teaching materials are also adjusted to the material's characteristics, whether it is suitable and suitable with the local culture of the Ngada ethnic group itself.

In the first test, researchers conducted trials on Multilingual teaching material products with the theme of 6 clean, healthy, and beautiful environments to experts, including content/material experts, regional language experts, Indonesian language experts, and product design experts. In this first test, the researcher only tested the product and was not accompanied by a questionnaire from the experts. Testing of content/material experts is not accompanied by filling out a questionnaire or questionnaire. The expert made revisions to the tested products by providing input and making changes that were in the use of capital letters in people's names and place names and the use of punctuation marks. Also, differences lie in the writing system and learning materials. For trials of regional linguists, the researcher submitted a problematic file of the product that had been prepared. Some sentences and words must be changed in regional language products. Changes made by experts include sentences, capital letters, and punctuation in certain words such as beti (sick), esa (one), peli (circle), ema (father), and others by adding sign schahwa $\left({ }^{\wedge}\right)$ above the letter e. Indonesian language experts' revisions lie in the use of capital letters, use of punctuation marks, and breaking sentences between paragraphs. The changes made by product design experts are related to writing, layout, and material supporting images. The order of presentation of the material must start from this -simple, concrete, and close to everyday life.

At the product revision stage (evaluation 1), researchers made revisions to products previously tested on experts. The researcher corrects all changes to the product made by experts. Corrections were created to improve the products developed by researchers. In the revisions for content/material experts, researchers looked back at experts' changes, such as using capital letters in people's names and place names and the use of punctuation marks. Besides, differences also lie in the writing system and learning materials. In capital letters, the researcher made changes to people's names and place names in the conversation text and story text. In punctuation, the researcher made changes and additions to message sentences and question sentences such as exclamation marks (!) And question marks (?). According to experts' input and changes, researchers made revisions to regional languages in teaching material products on July 11, 2020. Changes made include writing and reading grammar that must match those used in Ngadha languages such as B, BH, D, DH, G, GH, which are consonant sounds. Then the weak, pop, and schahwa sounds (a, 'a, e,' e, ê, I, 'i, o,' o, u, 'u), which are vowels, were also revised the researcher according to the direction of the expert. To the product according to changes and input made by Indonesian language experts on July 31, 2020. Revisions made include breaking sentences between paragraphs, punctuation marks, use of capital letters, and optimal continuity of text content. Modifications made to product design include inconsistent writing, layout, material supporting images, and numbering. Regarding the writing system, the researcher made changes to the inappropriate letters. Researchers make changes to investing ideas that are not by local culture.

Content/material experts provide product testing results (implementation stage 2) for the developed product, regional language experts, Indonesian language experts, and product design experts. The second stage of product testing by content/material experts was carried out on July 24, 2020. Testing of this product was accompanied by filling out a questionnaire by the expert. Expert test questionnaire data Material/content can be seen in table 1 .

Table 1. Results of the Material / Content Expert Questionnaire Test

\begin{tabular}{|r|l|c|}
\hline \multicolumn{1}{|c|}{$\begin{array}{c}\text { R } \\
\text { N }\end{array}$} & \multicolumn{1}{c|}{ Rated aspect } & $\begin{array}{c}\text { Sco } \\
\text { re }\end{array}$ \\
\hline 1 & Suitability of material with Core Competencies and Basic Competencies. & 4 \\
\hline 2 & The material presented is active, fun, and authentic. & 4 \\
\hline 3 & The material presented is by the level of thinking of elementary school students. & 5 \\
\hline
\end{tabular}




\begin{tabular}{|c|c|c|}
\hline 4 & Suitability of content with learning objectives. & 4 \\
\hline 5 & Suitability of content with the 2013 curriculum in elementary schools. & 5 \\
\hline 6 & $\begin{array}{l}\text { The suitability of the material depth level with the } 2013 \text { curriculum in elementary } \\
\text { schools. }\end{array}$ & 4 \\
\hline 7 & $\begin{array}{l}\text { Organizing teaching materials in terms of the conciseness of the presentation of the } \\
\text { material. }\end{array}$ & 4 \\
\hline 8 & $\begin{array}{l}\text { The organization of teaching materials is viewed from the systematic presentation of } \\
\text { the material. }\end{array}$ & 4 \\
\hline 9 & $\begin{array}{l}\text { Suitability of language choice with the level of development of elementary school } \\
\text { children. }\end{array}$ & 5 \\
\hline 1 & The effectiveness of using sentences. & 4 \\
\hline 1 & Proper use of grammar (subject composition, predicates, objects, and descriptions). & 4 \\
\hline $2^{1}$ & Accuracy of spelling (punctuation, affix). & 4 \\
\hline $3^{1}$ & The suitability of image media in clarifying messages/concepts. & 5 \\
\hline & The suitability of examples and cases in clarifying the concept. & 5 \\
\hline & Suitability of practice questions in supporting concept explanation. & 5 \\
\hline & $\begin{array}{l}\text { The suitability of the material's content with the development of information and } \\
\text { communication technology (ICT). }\end{array}$ & 4 \\
\hline $7^{1}$ & Ease of exploring the contents of printed teaching materials. & 4 \\
\hline 8 & Organizing learning activities that are designed to support culture-based learning. & 5 \\
\hline \multicolumn{2}{|r|}{ Total score } & 79 \\
\hline \multicolumn{2}{|r|}{ Average } & 4.4 \\
\hline \multicolumn{2}{|r|}{ Criteria } & $\begin{array}{r}\text { Ver } \\
\text { y good }\end{array}$ \\
\hline
\end{tabular}

From the calculations in table 1. an average of 4.4 is obtained. This percentage is included in the "Very Good" category. That way, this teaching material can be used.

The second stage of product testing by regional language experts was carried out on July 20, 2020. Testing of this product was accompanied by filling out a questionnaire by the expert. Data from the questionnaire test results for local linguists can be seen in table 2 .

Table 2. Results of the Regional Language Expert Test Questionnaire

\begin{tabular}{|c|c|c|}
\hline $\mathbf{N}$ & Rated aspect & $\begin{array}{l}\text { Sco } \\
\text { re }\end{array}$ \\
\hline 1 & $\begin{array}{l}\text { The accuracy of the sentence structure with the standard of the Bajawa regional } \\
\text { language }\end{array}$ & 4 \\
\hline 2 & The effectiveness of sentences in providing information & 4 \\
\hline 3 & The standard of the term Bajawa regional language & 3 \\
\hline 4 & Readability of written messages/information & 4 \\
\hline 5 & $\begin{array}{l}\text { The use of Bajawa regional language terms/words is by the level of children's } \\
\text { language development }\end{array}$ & 3 \\
\hline 6 & The conciseness and coherence between sentences & 4 \\
\hline 7 & Use of terms/words that are simple and easy to understand & 4 \\
\hline 8 & Consistency in the use of the term Bajawa regional language & 3 \\
\hline 9 & Use of communicative Bajawa regional language terms & 4 \\
\hline $0^{1}$ & The use of the term Bajawa language is appropriate in the context of the sentence & 4 \\
\hline 1 & The accuracy of meaning in the use of the Bajawa regional language & 4 \\
\hline
\end{tabular}


Creation Of Multilingual Teaching Materials Focused On Content And Background Of Ngada Culture For Primary $1^{\text {st }}$ Grade

\begin{tabular}{|c|c|c|}
\hline 21 & The accuracy of writing the Bajawa regional language & 3 \\
\hline \multicolumn{2}{|c|}{ Total score } & $\mathbf{4 4}$ \\
\hline \multicolumn{2}{|c|}{ Average } & $\mathbf{3 . 6}$ \\
\hline & Criteria & $\begin{array}{c}\text { Go } \\
\text { od }\end{array}$ \\
\hline
\end{tabular}

From the above calculations, the average is 3.6. This percentage is included in the "Good" category. That way, this teaching material can be used.

The second stage of product testing by Indonesian language experts was carried out on August 03, 2020. Testing of this product was accompanied by filling out a questionnaire by the expert. Indonesian expert test result data can be seen in table 3 .

Table 3. Indonesian Language Expert Test Questionnaire Results

\begin{tabular}{|r|l|r|}
\hline \multicolumn{1}{|c|}{ Rated aspect } & Sco \\
\hline 1 & Use consistent words, terms, and sentences & re \\
\hline 2 & Consistent use of font shapes and sizes & 5 \\
\hline 3 & Easy to read font shapes and sizes & 5 \\
\hline 4 & The size of the letters used is proportional & 4 \\
\hline 5 & Using proper sentence structure & 5 \\
\hline 6 & Short and straightforward sentences & 5 \\
\hline 7 & Using vocabulary appropriate to the level of student development & 4 \\
\hline 8 & The language used is excellent and correct & 5 \\
\hline 9 & The language used is simple, straightforward, and easy to understand & 5 \\
\hline & Total score & $\mathbf{4 3}$ \\
\hline & Average & $\mathbf{4 . 7}$ \\
\hline & Criteria & Ver \\
& & good \\
\hline
\end{tabular}

From the above calculations, an average of 4.7 is obtained. This percentage is included in the "Very Good" category. That way, this teaching material can be used.

The second stage of product testing by product design experts was carried out on August 8, 2020. This product testing was accompanied by filling out a questionnaire by the design expert. Product design expert test results data can be seen in table 4.

Table 4. Results of the Product Design Expert Test Questionnaire

\begin{tabular}{|c|c|c|}
\hline $\mathbf{o r}^{\mathbf{N}}$ & Rated aspect & re \\
\hline 1 & The charm of the cover design & 5 \\
\hline 2 & The accuracy of the typing layout & 4 \\
\hline 3 & Consistent use of spaces, titles, subtitles, and typing of material & 3 \\
\hline 4 & Kelengkapan komponen-komponen pada setiap bab bahan ajar. & 4 \\
\hline 5 & Clarity of writing/typing & 4 \\
\hline 6 & The accuracy of the presentation of the material & 4 \\
\hline 7 & The accuracy of placing tables, figures/pictures, and illustrations & 3 \\
\hline 8 & Clarity of the order of presentation of the material & 4 \\
\hline 9 & $\begin{array}{l}\text { Organizing teaching materials in terms of the conciseness of the presentation of the } \\
\text { material }\end{array}$ & 4 \\
\hline $0^{1}$ & $\begin{array}{l}\text { The organization of teaching materials is viewed from the systematic presentation of } \\
\text { the material }\end{array}$ & 4 \\
\hline 1 & Organizing learning activities designed to support culture-based learning & 4 \\
\hline \multicolumn{2}{|r|}{ Total score } & 43 \\
\hline \multicolumn{2}{|r|}{ Average } & 3.9 \\
\hline \multicolumn{2}{|r|}{ Criteria } & $\begin{array}{l}\text { Go } \\
\text { od }\end{array}$ \\
\hline
\end{tabular}


From the above calculations, the average is 3.9. This percentage is included in the "Good" category. That way, this teaching material can be used.

After assessing the multilingual teaching materials developed by the researcher, the product is said to be suitable for use without any revision from the experts. Furthermore, Multilingual teaching materials based on local culture can be used as a medium of learning. Ratings are given by content/material experts to products with excellent rating categories. In this assessment, there are no comments and suggestions given as revision material so that this teaching material is suitable for use. Indonesian language experts give ratings for products with excellent value categories. In this assessment, there are no comments and suggestions given as revision material so that this teaching material is suitable for use. After assessingthe Multilingual teaching materials developed by the researcher, the assessment given by the Regional Language experts of this teaching material was categorized as Good. In this assessment, there are no comments and suggestions given as revision material so that this teaching material is suitable for use. Design experts provide ratings for products with the Good value category. In this assessment, there are no comments and suggestions given as revision material so that this teaching material is suitable for use. Product refinement comes from observations and revisions provided by Content or Material Experts, Regional Language Experts, Indonesian Language Experts, and Design Experts. Researchers look back at the improvements made. The researcher then corrected the revision made by the expert. After all the improvements have been made, this teaching material can then be used. The final form of this teaching material development is Multilingual teaching materials based on content and the local cultural context of the ethnic Ngada. The results of this development can fulfill the availability of teaching materials based on fascinating local cultures.

\subsection{Discussion}

The development of multilingual teaching materials uses the ADDIE development model. This model consists of five steps, namely (1) analysis, (2) design, (3) development, (4) implementation, and (5) evaluation. This model's choice is based on the consideration that this model is developed systematically and is based on the theoretical foundation of learning design. This model is arranged programmatically with a systematic sequence of activities to solve learning problems related to learning resources that are bystudents' needs and characteristics.

Research that is in line with this development research is a research conducted by Laksana, et al (2016) entitled "Development of Thematic Teaching Materials for Class IV Elementary Schools Based on Local Wisdom of the Ngada Community". The results of research on the development of thematic teaching materials based on local wisdom based on the results of trials by experts and students as product users are as follows: (1) The content and context of local wisdom of the Ngada Community that are relevant to thematic learning themes in grade IV SD include regional potential, culture area, traditional house, regional arts. The teaching materials that will be developed later are the teaching materials for Theme 8, where I live. (2) Characteristics of thematic teaching materials based on local wisdom of the Ngada Community being developed, namely Mapping learning indicators, learning activities consisting of hand-on and mind activities, discussion activities, current information, and question exercises. (3) The teacher's response to thematic teaching materials based on the Ngada Community's local wisdom, namely the quality of the teaching materials produced, is in the excellent category. The highest score is in the presentation aspect, namely the attractiveness of the display of teaching materials. (4) Students' responses to thematic teaching materials based on the Ngada community's local wisdom, namely the quality of the teaching materials produced, is in the excellent category. The highest score is in the physical appearance of the teaching material and the legibility aspect of the size and type of letter. Thus, the development of this teaching material is suitable for use in grade IV elementary school students.

The teaching materials developed to consist of several main parts, namely: (1) cover, (2) title page, (3) introduction, (4) table of contents, (5) essential competencies, (6) sub-themes, (7) learning, (8) bibliography, (9) glossary. The teaching materials developed were then tested on experts and assessed by filling out a researcher's questionnaire. Several revisions, suggestions, and input regarding the teaching materials were generated from the test results, and the scores are given. Teaching materials developed by researchers are included in the type of printed teaching materials in books. The teaching materials developed by the researchers got an excellent category from the experts. This can be seen from the results of trials conducted by the content or material experts who gave a score of 79 with an average of 4.4 and the criteria "Very Good", regional language experts gave a score of 44 with an average of 3.6 and the requirements "Good", Indonesian language experts gave a score of 43 with an average of 4.7 and the criteria "Very Good," and product design experts gave a score of 43 with an average of 3.9 and criteria "Good". Based on the revisions and the scores provided by the experts, the Multilingual teaching materials based on content and the local cultural context of the Ngada ethnic group on 
theme 6 are clean, healthy, and beautiful environments suitable for use by grade 1 elementary school students. The summary of expert test results can be seen in table 5 .

Table 5. Summary of product expert test results

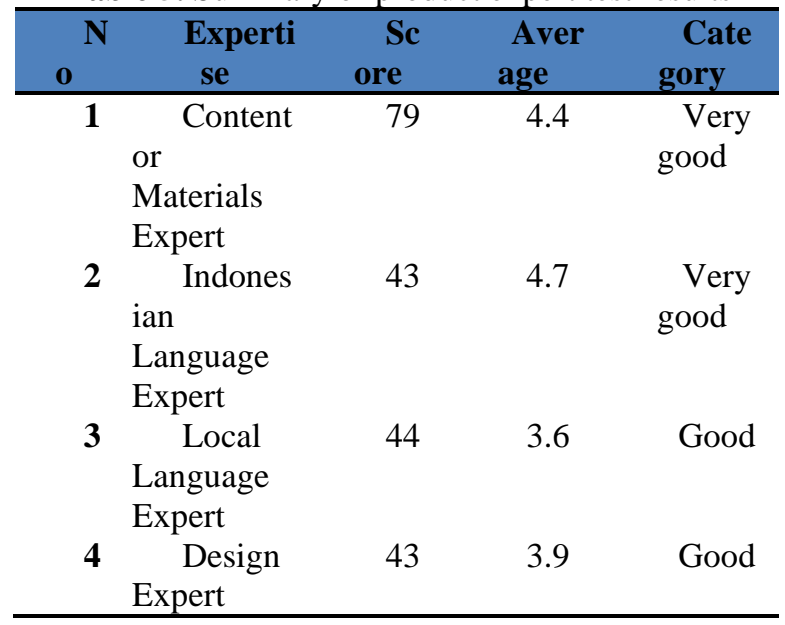

\section{Conclusion}

The development of multilingual teaching materials based on content and local ethnic, cultural contexts on the theme of 6 clean, healthy, and beautiful environments for grade 1 elementary school students to produce a multilingual teaching material product based on local culture. This teaching material consists of two languages, namely Indonesian and the local language of Ngada (Golewa ethnicity). The multilingual teaching materials' feasibilitywas developed in terms of the assessment results or validation of 1) from the content or material experts. The score is 79, with an average of 4.4. The Multilingual teaching materials are included in the "Very Good" category. 2) from the regional linguists, a score of 44 was obtained with an average of 3.6, so that the regional language in Multilingual teaching materials is in the "Good" category. 3) the Indonesian language expert obtained a score of 43 with an average of 4.7 so that Indonesian in multilingual teaching materials was included in the "Very Good" category. 4) From the product design expert, the score was 43 with an average of 3.9, so that the product design in multilingual teaching materials was included in the "Good" category. Thus, Multilingual teaching materials based on content and local ethnic, cultural contexts with the theme of 6 clean, healthy, and beautiful environments can be used.

\section{References}

1. Anderson, Lorin W \& Krathwohl, David R. 2010. A Taxonomy for Learning, Teaching, and Assessing. Arevision of Bloom's Taxonomy of Educational Objektives. Abridged Edition. Longman

2. Yang, C., Novaliendry, D., Chen, J., Wattimena, F. Y., Renyaan, A. S., Lizar, Y., ... Nasution, T. (2020). Prediction of Mortalityinthe Hemodialysis Patient with Diabetes using Support Vector Machine. Revista Argentina de Clínica Psicológica, XXIX, 219-232. https://doi.org/10.24205/03276716.2020.823

3. Novaliendry, D., Wattimena, F. Y., Renyaan, A. S., Lubis, A. S., Ramadhani, D., Lizar, Y., Guci, A., Rais, S., Sriwahyuni, T., Al Kutsi, M. I., Yang, C. H., Verawardina, U., Nasution, T., Khairul. (2020). Development of an Expert System Application to Detect Vitamin Deficiencies in the Human Body. Revista Argentina de Clínica Psicológica, XXIX, 956-965. https://doi.org/10.24205/03276716.2020.1092

4.D. Novaliendry,Y.Hendriyani, C-H.Yang, \& H. Hamimi, 2015, The Optimized K-Means Clustering Algorithms to Analyezed the Budget Revenue Expenditure in Padang. Proceeding of International Conference on Electrical Engineering, Computer Science and Informatics, 61-64

5. Belawati Tian,Tung K.Y.2006. Pengembangan Bahan ajar. Jakarta: Universitas Terbuka.

6. Lawe, Uge Yosefina .2021. Penggunaan Bahan Ajar Elektronik Multi Media Berbasis Budaya Lokal Pada Tema Daerah Tempat Tinggalku Untuk Meningkatkan Kemampuan Berpikir Tingkat Tinggi Sekolah Dasar. Jurnal

7. Lawe, Uge Yosefina, Dopo, Trifonia. 2019. Pengembangan bahan ajar elektronik multimedia berbasis budaya lokal ngada pada tema daerah tempat tinggalku untuk siswa sekolah dasar kelas IV di kabupaten ngada. Jurnal. http://jurnalilmiahcitrabakti.ac.id/jil/index.php/jil/article/view/38/41

8. Alexon. 2010. Pembelajaran terpadu berbasis budaya. Bengkulu: Unit FKIP UNIB Press.

9. Krismadinata, Unung Verawardina, Nizwardi Jalinus, Fahmi Rizal, Sukardi, Putu Sudira, Dochi Ramadhani, Arina Luthfini Lubis, John Friadi, Ari Syaiful Rahman Arifin, Dony Novaliendry. Blended Learning as Instructional Model in Vocational Education: Literature Review. Universal Journal of 
Educational Research, vol. 8, 11b, pp. 5801 - 5815, 2020. DOI: 10.13189/ujer.2020.082214

10. Novaliendry, D., Darmi, R., Hendriyani, Y., Nor, M., \& Azman, A. (2020). Smart Learning Media Based on Android Technology. International Journal of Innovation, Creativity and Change., 12(11), 715-735.

11. Molenda,M. 2003. In Search of the Elusive ADDIE Model. Performance improvement. Submitted for publication in A. Kovalchik \& K. Dawson, Ed's, Educational Technology: An Encyclopedias

12. Dony Novaliendry, Muhammad Adri, Putra Jaya, Titi Sriwahyuni, Asrul Huda, Yasdinul Huda, Dedy Irfan, Dochi Ramadhani, Sartika Anori. 2020. Development of Smart Learning Media Model Based on Android, International Journal of Engineering Research and Technology. ISSN 0974-3154, Volume 13, Number 12, pp. 5354-5364

13. Husein, Ismail H Mawengkang, S Suwilo "Modeling the Transmission of Infectious Disease in a Dynamic Network" Journal of Physics: Conference Series 1255 (1), 012052, 2019.

14. Husein, Ismail, Herman Mawengkang, Saib Suwilo, and Mardiningsih. "Modelling Infectious Disease in Dynamic Networks Considering Vaccine." Systematic Reviews in Pharmacy 11.2, pp. 261-266, 2020.

15. Husein, Ismail, Dwi Noerjoedianto, Muhammad Sakti, Abeer Hamoodi Jabbar. "Modeling of Epidemic Transmission and Predicting the Spread of Infectious Disease." Systematic Reviews in Pharmacy 11.6 (2020), 188-195. Print. doi:10.31838/srp.2020.6.30

16. Husein, Ismail, YD Prasetyo, S Suwilo "Upper generalized exponents of two-colored primitive extremal ministrong digraphs"AIP Conference Proceedings 1635 (1), 430-439, 2014

17. Husein Ismail, Rahmad Syah, "Model of Increasing Experiences Mathematics Learning with Group Method Project", International Journal of Advanced Science and Technology, pp. 1133-1138, 2020.

18. [13] Dony Novaliendry, Arif Subagia, Titi Sriwahyuni, Fegie Y Wattimena, Axelon S Renyaan, Ceng-Hong Yang, Putra Jaya. 2021. Designing Augmented Reality-Based Computer Devices Learning Media on Android Platform. 4th Forum in Research Science, and Technology (FIRST-T1-T2-2020). Atlantis Highlights in Engineering. 